\title{
Virtual screening for angiotensin I-converting enzyme inhibitory peptides from Phascolosoma esculenta
}

\author{
Yalan Liu', Lujia Zhang ${ }^{1}$, Mingrong Guo ${ }^{1}$, Hongxi Wu'², Jingli Xie ${ }^{1 *}$ and Dongzhi Wei ${ }^{1}$
}

\begin{abstract}
Background: Many short peptides have proved to exhibit potential anti-hypertensive activity through the inhibition of the Angiotensin I-converting enzyme (ACE) activity and the regulation of blood pressure. However, the traditional experimental screening method for ACE inhibitory peptides is time consuming and costly, accompanied with the limitations as incomplete hydrolysis and peptides loss during purification process. Virtual methods with the aid of computer can break such bottle-neck of experimental work. In this study, an attempt was made to establish a library of di- and tri-peptides derived from proteins of Phascolosoma esculenta, a kind of seafood, through BIOPEP (http://www.uwm.edu.pl/biochemia/index.php/pl/biopep), and to screen highly active ACE inhibitory peptides by molecular docking with the help of LibDock module of Discovery Studio 3.5 software.

Results: Two hundred and eighty four (284) di- and tri-peptides, derived from P. esculenta proteins after a virtual hydrolysis with pepsin, trypsin and a mixture of pepsin and trypsin, were predicted to possess ACE inhibitory activity, among which there are 99 ACE inhibitory peptides with estimated $I_{50}$ less than $50 \mu \mathrm{M}$. Nine peptides were synthesized for the comparison between the estimated and the experimentally determined $I C_{50}$. The results indicated that errors between the estimated and measured $\log \left(1 / \mathrm{IC}_{50}\right)$ are all less than 1.0 unit.
\end{abstract}

Conclusions: Virtual method for peptide library construction and ACE inhibitory peptides screening efficiently demonstrated that $P$. esculenta proteins are prospect resource for food-origin ACE inhibitory peptide.

Keywords: Virtual screening; Angiotensin I-converting enzyme (ACE); ACE inhibitory peptide; Phascolosoma esculenta

\section{Background}

Hypertension is a worldwide health problem, the prevalence of which have affected up to $30 \%$ of the adult population according to the World Health Organization. Hypertension carries a high-risk factor for arteriosclerosis, myocardial infarction, and end-stage renal disease $[1,2]$. It is predicted that by 2025 , about $20 \%$ of the world population will suffer from hypertension [3].

Although the cause of hypertension currently cannot be well determined, it is understood that the reninangiotensin system regulates an organism's water, electrolytes, and blood, and the angiotensin I-converting enzyme (ACE) (peptidyldipeptide hydrolase, EC 3.4.15.1) plays an

\footnotetext{
* Correspondence: jlxie@ecust.edu.cn

${ }^{1}$ State Key Laboratory of Bioreactor Engineering, Department of Food Science and Engineering, East China University of Science and Technology, 130\# Meilong Rd., P.O. Box 283, Shanghai 200237, People's Republic of China Full list of author information is available at the end of the article
}

important role in regulating the blood pressure [4]. ACE is a hypertension-responsible glycoprotein distributed in vascular endothelial, absorptive epithelial, and male germinal cells $[5,6]$. ACE cleaves the carboxyl terminal His-Leu dipeptide from inactive decapeptide angiotensin I to active angiotensin II, a powerful vasoconstrictor which can trigger hypertension [7-10]. ACE also influences the kallikrein-kinin system by promoting the degradation and inactivation of bradykinin, which can lead to reduction of hypertension. Therefore, excessive activity of ACE leads to hypertension. Molecules which can inhibit the activity of ACE are considered useful drugs for hypertension management [11]. Currently, synthetic ACE inhibitors, such as captopril, enalapril and lisinopril, are available on the market [12]; however, they tend to have side effects [13].

Since the discovery of the first anti-hypertensive peptide in snake venom [14], more attention has been paid to natural sources, especially peptides. Peptides derived 
from cheese whey [15], fermented milk [16], mushroom [17], soy bean $[18,19]$, corn gluten [20], insect protein [21], peanut flour [22], and egg [23] have been proven to inhibit the activity of ACE. However, few studies were reported about their side effects [24,25]. Nutritionists claim that peptides found in food are safer than 'traditional' drugs, and they are promising synthetic drug substitutes [26].

Among the ACE inhibitory peptides, shorter ones (di- and tri-peptides) usually have significant advantages over longer ones. They easily pass through blood circulation system $[27,28]$ and then reach action sites faster without being hydrolyzed by digestive enzymes during the gastrointestinal digestion $[29,30]$. For these reasons, the present study focused on di- and tripeptides.

The discovery of ACE inhibitory peptides with potential anti-hypertensive effect is mostly based on experiments, which require amounts of labors and funds. Besides, the possible active peptides can not be totally harvested due to the incomplete hydrolysis and peptides loss in the purification by the experimental protocols. Recently, as the computation simulation technology for drug design and discovery of molecular interaction are booming, the virtual screening or in silico experiment may replace the traditionally experimental screening of anti-hypertensive peptides to some extent. Computational approaches, which are based on computational evaluation of interactions between receptor and ligand, are proved feasible for virtual screening [31]. Molecular docking is a powerful and a widely used tool in molecular simulation, which is approximated to a lock-and-key process. The docking protocol is to 'dock' a ligand into an active site of a receptor; then, the interactions between them were 'scored' to assess the potential bioactivity of candidate compounds. The most advantage of docking is its high-throughput screening in short time with little cost [32].

In this study, an attempt was made to investigate the ACE inhibitory activity of di- and tri-peptides derived from Phascolosoma esculenta, a marine deposit-feeding benthonic invertebrates, also a traditional seafood with over $70 \%$ protein (dry weight) in Southeast China [33,34]. Database of di- and tri-peptides derived from $P$. esculenta were established, and their ACE inhibitory activities were predicted by virtual hydrolysis and screening method. Finally, di- and tri-peptides which have obvious ACE inhibitory activity were synthesized for verifying the validity of such virtual strategy.

\section{Methods}

Materials

There are 22 proteins of $P$. esculenta with the protein messages including entry name and sequence obtained from UniProt (http://www.uniprot.org/) (Table 1). They were used as original materials for database of di- and tri-peptides. With the help of BIOPEP (http://www. uwm.edu.pl/biochemia/index.php/pl/biopep), the 22 proteins were virtually hydrolyzed with pepsin, trypsin, and a mixture of pepsin and trypsin.

\section{Molecular docking experiments}

LibDock, a module of Discovery Studio 3.5 software (DS3.5, Accelrys, San Diego, CA, USA), was used for molecular docking experiments. Scoring results (LibDock score) about ligand-receptor combination were used as the final criterion to estimate the ACE inhibitory activity of ligands. Based on a previous study [35], the corresponding relationship between LibDock score and $\mathrm{IC}_{50}$ was

$$
\text { LibDock score }=10.063 \log \left(1 / \mathrm{IC}_{50}\right)+68.08,
$$

where $\mathrm{IC}_{50}$ is $50 \%$ inhibitory concentration (in $\mu \mathrm{M}$ ) towards ACE. According to the LibDock score, ACE inhibitory activity of ligands could be estimated.

Table 1 Properties of 22 P. esculenta proteins in UniProt (http://www.uniprot.org/)

\begin{tabular}{llll}
\hline Name & Number of amino acids & MW $(\mathbf{k D a})$ & PI \\
\hline D2JOB2 & 226 & 25.2 & 6.0 \\
C3PUI4 & 378 & 43.2 & 9.1 \\
D2J288 & 726 & 83.6 & 4.9 \\
C3PUI8 & 304 & 34.6 & 8.5 \\
C3PUI2 & 267 & 30.3 & 6.9 \\
B6CQR3 & 658 & 71.6 & 5.1 \\
A5A2J9 & 135 & 15.4 & 6.5 \\
C3PUI5 & 121 & 13.9 & 6.7 \\
B3TCX0 & 84 & 9.3 & 4.7 \\
C3PUJ0 & 571 & 63.3 & 9.2 \\
C3PUI9 & 231 & 25.7 & 5.9 \\
B6CPA3 & 120 & 13.63 & 5.8 \\
A5A2K2 & 220 & 24.4 & 5.8 \\
C3PUH9 & 519 & 57.2 & 6.2 \\
C3PUI7 & 450 & 50.2 & 9.2 \\
B3TFG2 & 174 & 20.2 & 5.1 \\
C3PUI1 & 54 & 6.5 & 10.8 \\
C3PUI3 & 157 & 17.7 & 9.5 \\
A3EX91 & 137 & 14.8 & 4.7 \\
C3PUJ1 & 323 & 36.1 & 9.1 \\
C3PUI0 & 231 & 25.9 & 4.8 \\
C3PUI6 & 94 & 10.5 & 9.2 \\
\hline MW & &
\end{tabular}

MW molecular weight, $P I$ isoelectric point. 
ACE was used as receptor in docking simulation, whose crystal structures was available in the Protein Data Bank (PDB) (http://www.pdb.org), from where the threedimensional structure of ACE was imported [PDB:1O8A]. Before the docking procedure, water molecules were removed and zinc ions were retained. The $284 \mathrm{di}-$ and tripeptides derived from $P$. esculenta were used as ligands, of which structures and energies were generated with ChemBioDraw software [36] and minimized with the CHARMM program [37], respectively. Parameters used in the docking process are shown in Table 2.

\section{Synthesis of peptides}

Five tri-peptides (GYF, WAL, AYF, GLR, and ILK) and four di-peptides (FK, QF, EL, and HK) generated through in silico hydrolysis of $P$. esculenta protein, with purity of $95 \%$, were synthesized by GL Biochem Co. Ltd. (Shanghai, China) for $\mathrm{IC}_{50}$ testing.

\section{Measurement of ACE inhibitory activity}

The ACE inhibitory activity was measured according to the method of Cushman and Cheung [38] with slight

Table 2 Parameters for molecular docking experiments performed with the LibDock of DS3.5

\begin{tabular}{|c|c|}
\hline Parameter name & Parameter value \\
\hline Docking sphere & $10 \AA$ \\
\hline \multicolumn{2}{|l|}{ Input site sphere } \\
\hline$x$ & 48.65 \\
\hline$y$ & 82.55 \\
\hline$z$ & 54.04 \\
\hline Number of HPTPot & 100 \\
\hline Docking tolerance & 0.25 \\
\hline Docking preference & User specified \\
\hline Max hits to save & 10 \\
\hline Max number of hits & 100 \\
\hline Minimum LibDock score & 100 \\
\hline Final score cutoff & 0.5 \\
\hline Max BFGS steps & 50 \\
\hline Rigid optimization & False \\
\hline Max conformation hits & 30 \\
\hline Max start conformations & 1,000 \\
\hline Steric fraction & 0.10 \\
\hline Final cluster radius & 0.5 \\
\hline Apolar SASA cutoff & 15.0 \\
\hline Polar SASA cutoff & 5.0 \\
\hline Surface grid steps & 18 \\
\hline Conformation method & Best \\
\hline Minimization algorithm & Do not minimize \\
\hline Parallel processing & True \\
\hline
\end{tabular}

modifications. Ten milligram of the sample was dissolved in $1 \mathrm{~mL}$ distilled water and then diluted to seven different concentrations for ACE inhibitory measurements. Fifteen microliters of the sample solution in certain concentration (Seven different concentrations) were needed, which were determined by the pre-experiment about ACE inhibition ratio. The whole principle is that the concentration which ACE inhibition ratio reaches $50 \%$ is included within the concentration range. The concentrations for GYF, FK, WAL, QF, and AYF are 10, 20, 30, 40, 50, 60, and $70 \mu \mathrm{g} / \mathrm{mL}$, and for EL, GLR, HK, and ILK are 20, 40, 60, $80,100,120$, and $140 \mu \mathrm{g} / \mathrm{mL}$, respectively) and $15 \mu \mathrm{L}$ substrate hippuryl-L-histidyl-L-leucine (HHL) (8.3 mM Hip-His-Leu in $50 \mathrm{mM}$ sodium borate buffer containing $0.5 \mathrm{M} \mathrm{NaCl}$ at $\mathrm{pH} 8.3$ ) were mixed together and then preincubated at $37^{\circ} \mathrm{C}$ for $5 \mathrm{~min}$. The reaction was initiated by adding $5 \mu \mathrm{L}$ of ACE solution $(310 \mathrm{mU} / \mathrm{mL})$ and incubated for $60 \mathrm{~min}$ at the same temperature. The reaction was terminated by the addition of $1.0 \mathrm{M} \mathrm{HCl}(200 \mu \mathrm{L})$. Ten microliters of the reaction solution was injected directly onto a Thermo BDS-C18 column $(3.0 \mathrm{~mm} \times 250 \mathrm{~mm}$, $5 \mu \mathrm{m}$, Thermo Scientific Co. Ltd., Waltham, MA, USA). The mobile phase consisted of 10\% acetonitrile and 90\% water with $0.1 \%$ trifluoroacetic acid (TFA). The flow rate was $0.7 \mathrm{~mL} / \mathrm{min}$ and the absorbance was monitored at $228 \mathrm{~nm}$. All determination was carried out at least in triplicate. The inhibition activity was calculated using the following equation:

$$
\text { ACE inhibition }(\%)=\left[1-\left(A_{\text {inhibitor }} / A_{\text {control }}\right)\right] \times 100,
$$

where $A_{\text {inhibitor }}$ is the absorbance with ACE, HHL, and sample, and $A_{\text {control }}$ is the absorbance of hippuric acid (HA) with ACE and HHL without the sample. Dose-dependent ACE inhibition was investigated using at least five different concentrations of peptides. The concentration of peptides that inhibited $\mathrm{ACE}$ activity by $50 \%$ ( $\mathrm{IC}_{50}$ ) was calculated using a non-linear regression from a plot of ACE inhibition versus sample concentrations.

\section{Study on structural-active relationship of ACE inhibitory peptides}

The chemical properties of C-terminal and N-terminal amino acids of 99 peptides with estimated $\mathrm{IC}_{50}$ less than $50 \mu \mathrm{M}$ were summarized to deduce the structural-active relationship of ACE inhibitory peptides.

\section{Results and discussion}

Pool of di- and tri-peptides derived from $P$. esculenta proteins Pepsin, trypsin, and the mixture of pepsin and trypsin were used to virtually hydrolyze the 22 proteins from $P$. esculenta, with the help of BIOPEP (http://www.uwm.edu. $\mathrm{pl} /$ biochemia/index.php/pl/biopep). In total, 2,667 peptides were virtually produced, and among them, 1,084 were di- 
and tri-peptides, which accounted for about $40.6 \%$ (Figure 1). After excluding the repeated ones, there were 1,017 nonrepeated peptides, among which 284 were di- and tripeptides. The sequences and the frequencies of these 284 short peptides are shown in Table 3. These 284 peptides were used as the ligands for docking experiment with ACE.

\section{Estimated $\mathrm{IC}_{50}$ distribution of ACE inhibitory di- and tri-peptides}

The estimated ACE inhibitory $\mathrm{IC}_{50}$ of the 284 di- and tripeptides derived from $P$. esculenta proteins were obtained according to LibDock scores, which were summarized in Figure 2. Ninety-nine (99) peptides had an estimated $\mathrm{IC}_{50}$ less than $50 \mu \mathrm{M}$ (34.9\% of 284 peptides), 100 peptides had an estimated $\mathrm{IC}_{50}$ between 50 and $100 \mu \mathrm{M}$ (35.2\% of 284 peptides), and 37 peptides had an estimated $\mathrm{IC}_{50}$ less than $500 \mu \mathrm{M}$, accounting for $13.0 \%$. Most reported ACE inhibitory peptides with $\mathrm{IC}_{50}$ less than $100 \mu \mathrm{M}$ showed potent in vivo anti-hypertensive activity [39]. Therefore, P. esculenta is a prospective anti-hypertensive peptide-containing resource since more than two thirds di- and tri-peptides theoretically possess obvious ACE inhibitory activity. The sequences and estimated $\mathrm{IC}_{50}$ of di- and tri-peptides with estimated $\mathrm{IC}_{50}$ less than $50 \mu \mathrm{M}$ are shown in Table 4 .

Short peptides were usually used for predicting potent ACE inhibitory activity. Pripp docked 58 di-peptides into protein target using the Molegro Virtual Docker version 1.1.1 software and found significant relationship between docking results and experimental $\mathrm{IC}_{50}$ values [32]. Several tri-peptides consisting of I or $\mathrm{L}$ and positive charged amino acids and aromatic amino acids were synthesized, and their ACE inhibitory activities were measured to clarify the amino acid sequence for inhibition of ACE [40]. Larger peptides, for instance, the sequence length more than 5, were also focused in some work [41]; however, such works were reported with lower $R^{2}$ (coefficient of variation) because of the complexity in the modeling due to the bigger peptide $[42,43]$.

\section{Confirmation of virtual screening method}

In order to confirm the validity of virtual screening method of the present work, nine peptides were synthesized for $\mathrm{IC}_{50}$ testing. The sequences of these peptides were obtained from $P$. esculenta protein through virtual hydrolysis and screening by docking experiments. The estimated $\log (1 /$ $\left.\mathrm{IC}_{50}\right)$ and measured $\log \left(1 / \mathrm{IC}_{50}\right)$ of the nine peptides were compared (Table 5). The error between the estimated log $\left(1 / \mathrm{IC}_{50}\right)$ and measured $\log \left(1 / \mathrm{IC}_{50}\right)$ is less than 1.0 unit. Desirable limit for model is that the error between estimated $\log \left(1 / \mathrm{IC}_{50}\right)$ and measured $\log \left(1 / \mathrm{IC}_{50}\right)$ is less than 1.5 units [30]. A reported quantitative structure-activity relationship (QSAR) model was constructed on 168 dipeptides and 140 tri-peptides collected from literatures, and the model verification was made on seven reported dipeptides and tri-peptides (not included in 168 di-peptides and 140 tri-peptides), of which the error was between 0.07 and 1.39 [29]. On the ground of such criterion, the present model is efficient and credible.

Previous studies suggested that the structural-active relationship of ACE inhibitory peptides largely depended on their amino acid composition, sequence, and configuration, though the full mechanism of interaction between peptides and ACE is not established so far $[44,45]$. For the short peptides as di- and tri-peptides, the amino acid composition and configuration are more significant. The di- and tri-peptides which have an estimated $\mathrm{IC}_{50}$ within $50 \mu \mathrm{M}$ were used to study the structural-active relationship of these ACE inhibitors.

There are four kinds of C-terminal residues for 99 sequences (Figure 3) due to the cutting specificity of pepsin

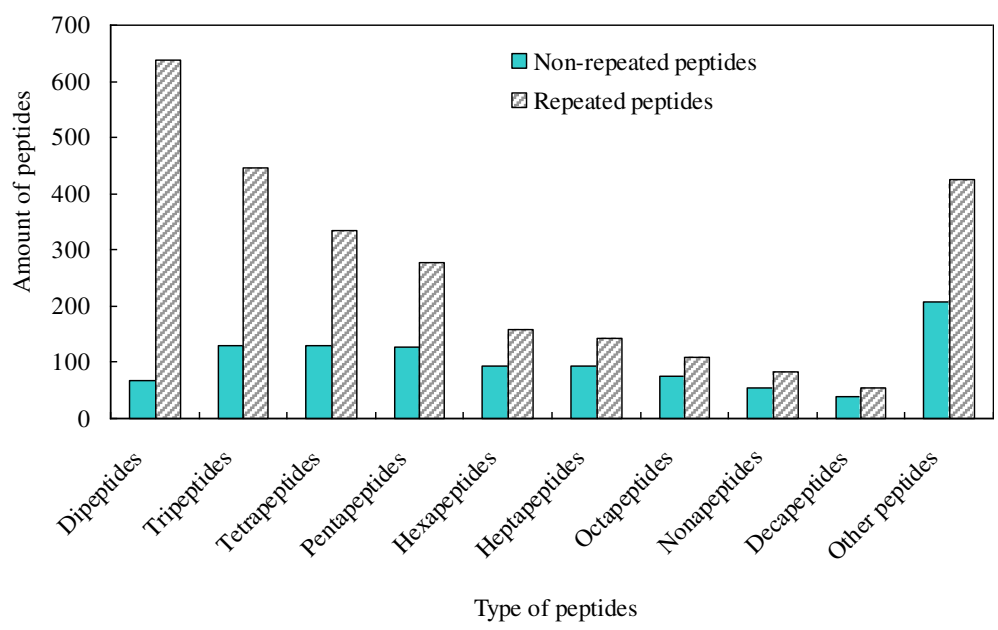

Figure 1 Length distribution of peptides derived from $P$. esculenta proteins by virtual hydrolysis. The enzymes used in virtual hydrolysis are pepsin, trypsin, and a mixture of pepsin and trypsin. 
Table 3 Sequence and frequency of di- and tri-peptides derived from $P$. esculenta proteins by virtual hydrolysis

\begin{tabular}{|c|c|c|c|c|c|c|c|}
\hline Peptide & Frequency & Peptide & Frequency & Peptide & Frequency & Peptide & Frequency \\
\hline$\overline{\mathrm{ADL}}$ & 1 & GYF & 2 & NDK & 2 & STL & 2 \\
\hline AEF & 2 & HAQ & 2 & NF & 10 & SVF & 2 \\
\hline AEK & 1 & HER & 1 & NGK & 1 & SVL & 4 \\
\hline AEL & 2 & $\mathrm{HF}$ & 9 & NIL & 2 & SWK & 2 \\
\hline AF & 19 & $\mathrm{HGL}$ & 2 & NK & 2 & SWL & 2 \\
\hline AGF & 2 & HIK & 2 & $\mathrm{NL}$ & 13 & SYL & 1 \\
\hline AlF & 4 & $\mathrm{HK}$ & 4 & NLK & 1 & TAL & 2 \\
\hline AK & 2 & HKF & 1 & NMR & 1 & TDK & 1 \\
\hline$A L$ & 35 & $\mathrm{HL}$ & 17 & NPF & 6 & TDR & 1 \\
\hline ALR & 1 & HSL & 2 & $N R$ & 2 & TEF & 2 \\
\hline AMF & 2 & HTK & 1 & NRF & 2 & TF & 7 \\
\hline APF & 2 & HTL & 1 & NSF & 2 & TGF & 2 \\
\hline AQF & 2 & IAR & 2 & NTL & 3 & TGL & 4 \\
\hline$A R$ & 2 & $\mathrm{ICL}$ & 4 & NVL & 5 & $\mathrm{TIL}$ & 2 \\
\hline ASK & 1 & IF & 20 & NVR & 2 & TK & 4 \\
\hline AVK & 2 & IGR & 1 & NWL & 2 & $\mathrm{TL}$ & 31 \\
\hline AVR & 2 & $\mathbb{H R}$ & 2 & PCK & 1 & TLK & 1 \\
\hline AYA & 2 & IIL & 4 & PDL & 2 & TML & 2 \\
\hline AYF & 3 & IK & 7 & PF & 19 & TNR & 1 \\
\hline CF & 2 & $\mathrm{IL}$ & 46 & PGF & 2 & TPF & 1 \\
\hline CK & 1 & ILK & 1 & PIL & 2 & TSL & 4 \\
\hline $\mathrm{CL}$ & 9 & IMF & 2 & PK & 7 & TTK & 1 \\
\hline CVF & 2 & IMK & 2 & PKL & 1 & TVK & 1 \\
\hline DF & 4 & IPK & 2 & $P L$ & 30 & TVL & 2 \\
\hline DK & 16 & $\mathrm{IPL}$ & 5 & PNK & 2 & TVR & 1 \\
\hline $\mathrm{DL}$ & 11 & IQK & 2 & PPL & 2 & TWK & 1 \\
\hline DMF & 2 & $\mathbb{I R}$ & 4 & PRL & 1 & TYF & 2 \\
\hline DNR & 1 & IRF & 1 & PSF & 2 & VAL & 6 \\
\hline DPK & 1 & ISF & 2 & PSK & 1 & VDL & 2 \\
\hline DR & 4 & ISL & 2 & PSL & 2 & VEK & 3 \\
\hline DSK & 2 & ISR & 1 & PTL & 4 & VER & 2 \\
\hline DSL & 4 & ITK & 1 & PTR & 2 & VF & 9 \\
\hline DWL & 1 & ITL & 2 & PVK & 1 & VGF & 6 \\
\hline EAF & 2 & $\mathrm{IVL}$ & 1 & PVL & 2 & VGL & 3 \\
\hline EAR & 1 & IWL & 4 & QAL & 2 & $\mathrm{VIR}$ & 3 \\
\hline EDK & 2 & KAL & 1 & QDF & 2 & VK & 2 \\
\hline EEF & 1 & $\mathrm{KDL}$ & 2 & QEL & 2 & VKL & 1 \\
\hline EEL & 2 & $\mathrm{KF}$ & 2 & QF & 5 & $\mathrm{VL}$ & 14 \\
\hline EER & 1 & KGF & 1 & QGL & 2 & VMK & 2 \\
\hline $\mathrm{EF}$ & 2 & $\mathrm{KIL}$ & 1 & QIR & 1 & VML & 2 \\
\hline EGL & 1 & $\mathrm{KL}$ & 4 & QK & 2 & VNL & 4 \\
\hline EIF & 1 & KPL & 1 & $\mathrm{QL}$ & 7 & VPK & 1 \\
\hline EIL & 1 & KRF & 1 & QR & 1 & VPL & 4 \\
\hline EK & 7 & KSL & 1 & QYK & 1 & VSF & 2 \\
\hline
\end{tabular}


Table 3 Sequence and frequency of di- and tri-peptides derived from $P$. esculenta proteins by virtual hydrolysis (Continued)

\begin{tabular}{|c|c|c|c|c|c|c|c|}
\hline$\overline{E L}$ & 16 & $\mathrm{KTL}$ & 1 & RAL & 1 & VSL & 3 \\
\hline EML & 1 & KVF & 1 & REL & 1 & WF & 2 \\
\hline ENK & 2 & LDK & 1 & $\mathrm{RL}$ & 3 & WK & 2 \\
\hline ENL & 6 & LEK & 1 & RPF & 1 & WAF & 2 \\
\hline ER & 2 & LK & 2 & RSF & 2 & WAL & 2 \\
\hline ESK & 1 & LMK & 1 & RTL & 1 & WCF & 2 \\
\hline ETL & 3 & $L R$ & 1 & SAL & 4 & WF & 6 \\
\hline EVK & 1 & LSK & 1 & SEK & 1 & WGK & 2 \\
\hline EVL & 4 & MAL & 8 & SF & 20 & $W L$ & 8 \\
\hline FFK & 1 & MF & 16 & SGF & 4 & WML & 2 \\
\hline FK & 1 & MFK & 1 & $\mathrm{SGL}$ & 2 & WNF & 2 \\
\hline FWR & 1 & MFR & 1 & $\mathrm{SHL}$ & 2 & WPF & 2 \\
\hline $\mathrm{GAL}$ & 2 & MGF & 2 & SIF & 2 & WQK & 2 \\
\hline GF & 12 & MGL & 2 & SIK & 2 & WR & 1 \\
\hline GGL & 4 & MIK & 2 & SIL & 4 & WTR & 1 \\
\hline GGR & 2 & MIL & 2 & SK & 6 & WWF & 2 \\
\hline GK & 6 & MK & 10 & $S L$ & 50 & YAL & 1 \\
\hline GKF & 1 & MKF & 2 & $\mathrm{SNL}$ & 3 & YF & 7 \\
\hline $\mathrm{GL}$ & 29 & $M L$ & 16 & SPF & 2 & YIF & 2 \\
\hline GLR & 1 & MPL & 1 & $\mathrm{SPL}$ & 2 & YIK & 1 \\
\hline GNL & 2 & MR & 4 & SQL & 2 & YK & 4 \\
\hline GR & 3 & MSK & 2 & $S R$ & 2 & $Y L$ & 8 \\
\hline GSL & 2 & MSL & 10 & SS & 2 & YPL & 2 \\
\hline $\mathrm{GTL}$ & 4 & MTK & 2 & SSF & 6 & YS & 2 \\
\hline GTR & 2 & MTL & 2 & SSL & 2 & YSK & 3 \\
\hline GVK & 1 & MVK & 2 & STF & 2 & YTL & 2 \\
\hline GWL & 2 & NAL & 2 & STK & 1 & YVR & 1 \\
\hline
\end{tabular}

The enzymes used in virtual hydrolysis are pepsin, trypsin, and a mixture of pepsin and trypsin.

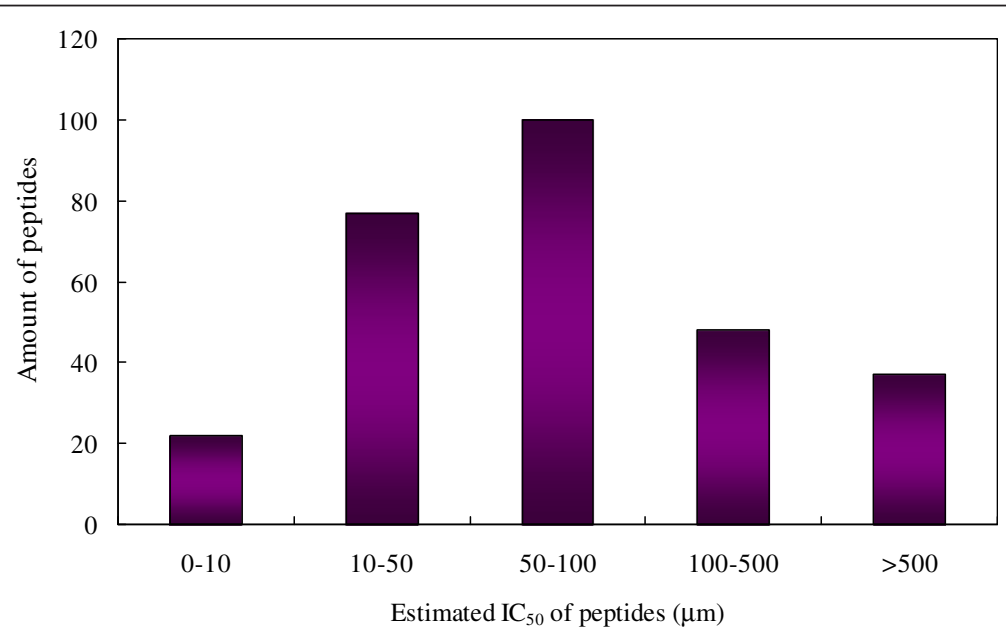

Figure 2 Distribution of estimated $\mathrm{IC}_{\mathbf{5 0}}$ of di- and tri-peptides with ACE inhibitory activity. The peptides were derived from $P$. esculenta proteins. All IC $C_{50}$ values were predicted by LibDock scores according to the equation, LibDock score $=10.063 \log (1 / \operatorname{lC} 50)+68.08$. 
Table 4 Di- and tri-peptides derived from $P$. esculenta with estimated $I C_{50}$ less than $50 \mu \mathrm{M}$

\begin{tabular}{|c|c|c|c|c|c|}
\hline Peptide & $\begin{array}{l}\text { Estimated } \\
\mathrm{IC}_{50}\end{array}$ & Peptide & $\begin{array}{l}\text { Estimated } \\
\mathrm{IC}_{50}\end{array}$ & Peptide & $\begin{array}{l}\text { Estimated } \\
\mathrm{IC}_{50}\end{array}$ \\
\hline WNF & 0.12 & YIF & 13.1 & DSL & 27.9 \\
\hline HKF & 0.42 & RPF & 13.3 & $\mathbb{R}$ & 28.9 \\
\hline WCF & 0.47 & APF & 13.4 & TGF & 29.5 \\
\hline WPF & 0.85 & REL & 13.7 & NWL & 30.7 \\
\hline WWF & 1.18 & YK & 13.9 & FFK & 30.9 \\
\hline YVR & 1.45 & AEF & 14.1 & GYF & 32.2 \\
\hline NRF & 1.71 & AYF & 14.7 & ISF & 32.3 \\
\hline TYF & 1.75 & KTL & 14.8 & FK & 33.2 \\
\hline IHR & 2.06 & WGK & 14.9 & SPF & 33.4 \\
\hline WML & 2.15 & DWL & 14.9 & VML & 33.7 \\
\hline WAF & 3.27 & SSF & 15.0 & $\mathrm{KPL}$ & 36.1 \\
\hline IWL & 5.22 & NSF & 15.4 & ISL & 36.5 \\
\hline RSF & 5.44 & VKL & 16.1 & QF & 36.7 \\
\hline IRF & 5.72 & MAL & 16.3 & TML & 36.9 \\
\hline CVF & 7.15 & $N R$ & 17.0 & QEL & 37.0 \\
\hline YIK & 7.33 & MTL & 17.1 & MKF & 38.0 \\
\hline MGF & 7.38 & IMF & 17.5 & YAL & 38.6 \\
\hline YF & 7.48 & WR & 17.7 & EEF & 40.4 \\
\hline KRF & 8.11 & $E R$ & 18.1 & IGR & 40.5 \\
\hline SR & 9.05 & AEL & 19.4 & TEF & 41.1 \\
\hline GNL & 9.09 & QDF & 19.5 & TTK & 41.6 \\
\hline GKF & 9.51 & YTL & 19.7 & SGF & 41.6 \\
\hline WTR & 10.2 & PIL & 19.9 & KVF & 42.0 \\
\hline PRL & 10.2 & $\mathrm{KDL}$ & 20.2 & $\mathrm{SIL}$ & 43.0 \\
\hline SYL & 10.4 & SVF & 20.8 & EVL & 43.7 \\
\hline WF & 10.6 & YSK & 21.5 & DMF & 46.6 \\
\hline IIL & 10.8 & WF & 22.5 & RTL & 46.9 \\
\hline WAL & 11.3 & ITK & 22.6 & QAL & 47.0 \\
\hline $\mathrm{AQF}$ & 11.5 & $\mathrm{DR}$ & 23.4 & TPF & 47.0 \\
\hline RAL & 11.8 & WQK & 23.9 & HSL & 47.1 \\
\hline PGF & 12.2 & PKL & 24.9 & NAL & 47.1 \\
\hline NVL & 12.7 & EIF & 25.2 & $\mathrm{SHL}$ & 48.0 \\
\hline HTL & 13.1 & VGF & 27.8 & STF & 49.4 \\
\hline
\end{tabular}

and trypsin. Leu and Phe are C-terminal residues formed by pepsin hydrolysis, and C-terminal Lys and Arg are formed by trypsin reaction. Hydrophobic C-terminal (Phe and Leu) is dominant in amount and accounts for more than 80\% peptides ( $44.4 \%$ and $36.4 \%$, respectively). There are some accepted concepts about the structure-activity relationship of ACE inhibitory peptides, such as that peptides with hydrophobic amino acid in C-terminus showed a highly potent ACE inhibitory activity [46]. Highly active peptide in general should be composed of large, hydrophobic, and
Table 5 Estimated and measured $\log \left(1 / I C_{50}\right)$ of the nine synthesized peptides derived from $P$. esculenta

\begin{tabular}{llll}
\hline Peptide & Estimated $\log \left(\mathbf{1} / \mathbf{I} \mathbf{C}_{\mathbf{5 0}}\right)$ & Measured $\log \left(\mathbf{1} / \mathbf{I} \mathbf{C}_{\mathbf{5 0}}\right)$ & Error \\
\hline GYF & 4.49 & $4.31 \pm 0.02$ & 0.18 \\
FK & 4.79 & $4.27 \pm 0.01$ & 0.52 \\
WAL & 4.95 & $4.38 \pm 0.04$ & 0.57 \\
QF & 4.44 & $4.21 \pm 0.03$ & 0.23 \\
AYF & 4.83 & $4.18 \pm 0.01$ & 0.65 \\
EL & 3.19 & $3.43 \pm 0.02$ & -0.24 \\
GLR & 4.07 & $3.61 \pm 0.02$ & 0.46 \\
HK & 3.53 & $3.86 \pm 0.01$ & -0.33 \\
ILK & 4.09 & $3.72 \pm 0.03$ & 0.37 \\
\hline
\end{tabular}

aromatic amino acid with a polar functional group in Cterminus [47]; and the physicochemical attributes of amino acids such as hydrophobicity, bulkiness, and electronic properties had impacts on the bioactivity of peptides [48]. Accordingly, benzene ring in Phe can also increase the bulkiness and bring about the stability of binding between $\mathrm{ACE}$ and peptide and sequentially result in high ACE inhibitory activity.

There are 40 peptides among 99 peptides (40.4\%) with hydrophobic amino acid at N-terminal, 38 peptides with neutral amino acid at $\mathrm{N}$-terminal (38.4\%), and $21.9 \%$ peptides with positively or negatively charged amino acid at $\mathrm{N}$-terminal (Figure 4). N-terminal amino acid of ACE inhibitory peptides also favors the hydrophobic interactions with ACE $[7,30]$. The peptides with hydrophobic amino acid at N-terminal showing higher ACE inhibitory activity have some superiority in amount in the present study, which verified such view.

\section{Conclusions}

A virtual method of hydrolysis and screening of ACE inhibitory peptides with high activity such as $\mathrm{IC}_{50}$ value $<50 \mu \mathrm{M}$ was constructed in this work. Ninety-nine (99) peptides were obtained from 22 proteins of $P$. esculenta. Besides, the efficiency and the validity of such method were verified by comparing the predicted $\mathrm{IC}_{50}$ and measured

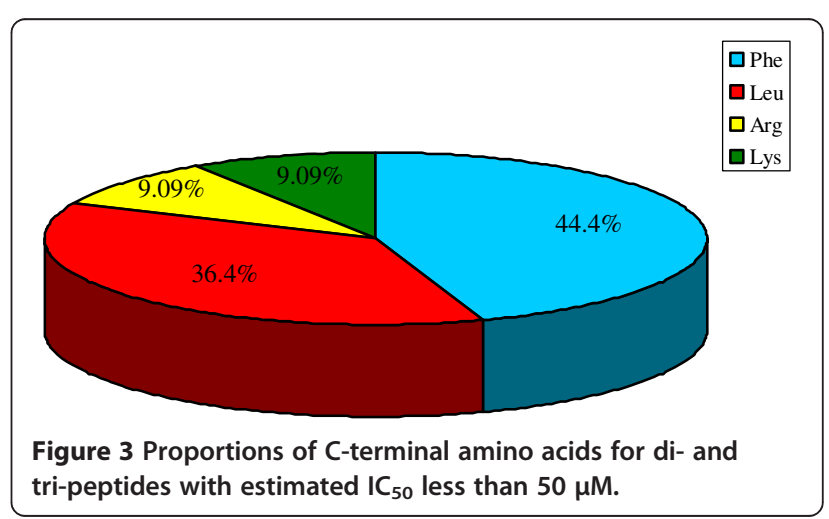




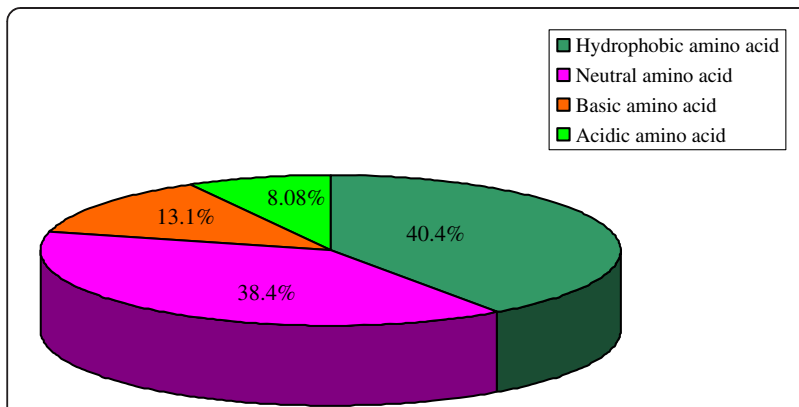

Figure 4 Proportions of $\mathrm{N}$-terminal amino acids for di- and tripeptides with estimated $\mathrm{IC}_{50}$ less than $50 \mu \mathrm{M}$.

$\mathrm{IC}_{50}$ of some synthesized peptides among the 99 peptides. The results demonstrated that the virtual hydrolysis and screening method is an efficient way that greatly cuts down the experimental labor to get highly active ACE inhibitory peptides. Moreover, P. esculenta proteins were proved as a good resource of ACE inhibitory peptides, which could be a beneficial ingredient for functional foods or pharmaceuticals against hypertension. Further research on larger antihypertension peptides derived from P. esculenta and in vivo activity testing will be carried out.

\section{Competing interests}

The authors declare that they have no competing interests.

\section{Authors' contributions}

YL carried out the establishment of pool of di- and tri-peptides derived from $P$. esculenta proteins and molecular docking experiments. MG carried out the measurement of ACE inhibitory activity. JX designed the study and revised the manuscript. HW performed the statistical analysis and partly revised the manuscript. LZ participated in part of the method establishment. DW conceived of the study and participated in the design and coordination. All authors read and approved the final manuscript.

\section{Acknowledgements}

This work was supported by 'National Natural Science Foundation of China (No. 31301413)', 'National Major Science and Technology Projects of China (No. 2012ZX09304009)', and the 'Fundamental Research Funds for the Central Universities', People's Republic of China.

\section{Author details}

'State Key Laboratory of Bioreactor Engineering, Department of Food Science and Engineering, East China University of Science and Technology, 130\# Meilong Rd., P.O. Box 283, Shanghai 200237, People's Republic of China. ${ }^{2}$ Zhejiang Key Lab of Exploitation and Preservation of Coastal Bio-resource, Wenzhou 325005, People's Republic of China.

Received: 3 July 2014 Accepted: 4 September 2014 Published online: 09 October 2014

\section{References}

1. Jung WK, Mendis E, Je JY, Park PJ, Son BW, Kim HC, Choi YK, Kim SK (2006) Angiotensin I-converting enzyme inhibitory peptide from yellowfin sole (Limanda aspera) frame protein and its antihypertensive effect in spontaneously hypertensive rats. Food Chem 94(1):26-32

2. Silva DG, Freitas MP, da Cunha EFF, Ramalho TC, Nunes CA (2012) Rational design of small modified peptides as ACE inhibitors. Med Chem Comm 3 (10):1290-1293

3. Kearney PM, Whelton M, Reynolds K, Muntner P, Whelton PK, He J (2005) Global burden of hypertension: analysis of worldwide data. Lancet 365 (9455):217-223
4. Li GH, Le GW, Shi YH, Shrestha S (2004) Angiotensin I-converting enzyme inhibitory peptides derived from food proteins and their physiological and pharmacological effects. Nutr Res 24(7):469-486

5. Guang C, Phillips RD (2009) Plant food-derived angiotensin I converting enzyme inhibitory peptides. J Agric Food Chem 57(12):5113-5120

6. De Leo F, Panarese S, Gallerani R, Ceci L (2009) Angiotensin converting enzyme (ACE) inhibitory peptides: production and implementation of functional food. Curr Pharm Des 15(31):3622-3643

7. Iroyukifujita H, Eiichiyokoyama K, Yoshikawa M (2000) Classification and antihypertensive activity of angiotensin I-converting enzyme inhibitory peptides derived from food proteins. J Food Sci 65(4):564-569

8. Reneland R, Lithell H (1994) Angiotensin-converting enzyme in human skeletal muscle. A simple in vitro assay of activity in needle biopsy specimens. Scand J Clin Lab Investig 54(2):105-111

9. Hartl FU (1996) Molecular chaperones in cellular protein folding. Nature 381:571-580

10. Sturrock E, Natesh R, Van Rooyen J, Acharya K (2004) Structure of angiotensin I-converting enzyme. Cell Mol Life Sci 61:2677-2686

11. Lin L, LV S, Li B (2012) Angiotensin---converting enzyme (ACE)-inhibitory and antihypertensive properties of squid skin gelatin hydrolysates. Food Chem 131(1):225-230

12. Sweitzer NK (2003) What is an angiotensin converting enzyme inhibitor? Circulation 108(3):e16-e18

13. Antonios TF, MacGregor GA (1995) Angiotensin converting enzyme inhibitors in hypertension: potential problems. J Hypertens 13:S11-S16

14. Ondetti MA, Williams NJ, Sabo E, Pluscec J, Weaver ER, Kocy O (1971) Angiotensin-converting enzyme inhibitors from the venom of Bothrops jararaca. Isolation, elucidation of structure, and synthesis. Biochemistry 10 (22):4033-4039

15. Abubakar A, Saito T, Kitazawa H, Kawai Y, Itoh T (1998) Structural analysis of new antihypertensive peptides derived from cheese whey protein by proteinase K digestion. J Dairy Sci 81(12):3131-3138

16. Nakamura Y, Yamamoto N, Sakai K, Okubo A, Yamazaki S, Takano T (1995) Purification and characterization of angiotensin I-converting enzyme inhibitors from sour milk. J Dairy Sci 78(4):777-783

17. Andújar-Sánchez M, Cámara-Artigas A, Jara-Pérez V (2004) A calorimetric study of the binding of lisinopril, enalaprilat and captopril to angiotensinconverting enzyme. Biophys Chem 111(2):183-189

18. Wu J, Ding X (2001) Hypotensive and physiological effect of angiotensin converting enzyme inhibitory peptides derived from soy protein on spontaneously hypertensive rats. J Agric Food Chem 49(1):501-506

19. Mallikarjun Gouda K, Gowda LR, Rao AA, Prakash V (2006) Angiotensin I-converting enzyme inhibitory peptide derived from glycinin, the $11 \mathrm{~S}$ globulin of soybean (Glycine max). J Agric Food Chem 54(13):4568-4573

20. Suh H, Whang J, Lee H (1999) A peptide from corn gluten hydrolysate that is inhibitory toward angiotensin I converting enzyme. Biotechnol Lett 21 (12):1055-1058

21. Vercruysse L, Van Camp J, Morel N, Rougé P, Herregods G, Smagghe G (2010) Ala-Val-Phe and Val-Phe: ACE inhibitory peptides derived from insect protein with antihypertensive activity in spontaneously hypertensive rats. Peptides 31(3):482-488

22. Quist EE, Phillips RD, Saalia FK (2009) Angiotensin converting enzyme inhibitory activity of proteolytic digests of peanut (Arachis hypogaea L.) flour. LWT-Food Sci Technol 42(3):694-699

23. Majumder K, Wu J (2009) Angiotensin I converting enzyme inhibitory peptides from simulated in vitro gastrointestinal digestion of cooked eggs. J Agric Food Chem 57(2):471-477

24. Wang C, Tian J, Wang Q (2011) ACE inhibitory and antihypertensive properties of apricot almond meal hydrolysate. Eur Food Res Technol 232(3):549-556

25. Vermeirssen V, Camp JV, Verstraete W (2004) Bioavailability of angiotensin I converting enzyme inhibitory peptides. Br J Nutr 92(03):357-366

26. Jimsheena V, Gowda LR (2011) Angiotensin I-converting enzyme (ACE) inhibitory peptides derived from arachin by simulated gastric digestion. Food Chem 125(2):561-569

27. Seppo L, Jauhiainen T, Poussa T, Korpela R (2003) A fermented milk high in bioactive peptides has a blood pressure-lowering effect in hypertensive subjects. Am J Clin Nutri 77(2):326-330

28. Mathews D, Adibi S (1976) Peptide absorption. Gastroenterology 71(1):151

29. Wu J, Aluko RE, Nakai S (2006) Structural requirements of angiotensin I-converting enzyme inhibitory peptides: quantitative structure-activity relationship study of di-and tripeptides. J Agric Food Chem 54(3):732-738 
30. Wijesekara I, Qian ZJ, Ryu B, Ngo DH, Kim SK (2011) Purification and identification of antihypertensive peptides from seaweed pipefish (Syngnathus schlegeli) muscle protein hydrolysate. Food Res Int 44(3):703-707

31. Berman HM, Westbrook J, Feng Z, Gilliland G, Bhat T, Weissig H, Shindyalov IN, Bourne PE (2000) The Protein Data Bank. Nucleic Acids Res 28(1):235-242

32. Pripp AH (2007) Docking and virtual screening of ACE inhibitory dipeptides. Eur Food Res Technol 225(3-4):589-592

33. Su X, Du L, Li Y, Li T, Li D, Wang M, He J (2009) Production of recombinant protein and polyclonal mouse antiserum for ferritin from Sipuncula Phascolosoma esculenta. Fish Shellfish Immunol 27(3):466-468

34. Du L, Fang $\mathrm{M}$, Wu H, Xie J, Wu Y, Li P, Zhang D, Huang Z, Xia Y, Zhou L (2013) A novel angiotensin I-converting enzyme inhibitory peptide from Phascolosoma esculenta water-soluble protein hydrolysate. J Funct Foods 5(1):475-483

35. Wu H, Liu Y, Guo M, Xie J, Jiang X (2014) A virtual screening method for inhibitory peptides of angiotensin I converting enzyme. J Food Sci 79: C1635-C1642, doi:10.1111/1750-3841.12559

36. Kerwin SM (2010) ChemBioOffice Ultra 2010 suite. J Am Chem Soc 132(7):2466-2467

37. Brooks BR, Bruccoleri RE, Olafson BD, States DJ, Swaminathan S, Karplus M (1983) CHARMM: a program for macromolecular energy, minimization, and dynamics calculations. J Comput Chem 4(2):187-217

38. Cushman D, Cheung H (1971) Spectrophotometric assay and properties of the angiotensin-converting enzyme of rabbit lung. Biochem Pharmacol 20(7):1637-1648

39. Iwaniak A, Minkiewicz P, Darewicz M (2014) Food-originating ACE inhibitors, including antihypertensive peptides, as preventive food components in blood pressure reduction. Compr Rev Food Sci Food Safety 13(2):114-134

40. Kobayashi Y, Yamauchi T, Katsuda T, Yamaji H, Katoh S (2008) Angiotensin-I converting enzyme (ACE) inhibitory mechanism of tripeptides containing aromatic residues. J Biosci Bioeng 106(3):310-312

41. Sagardia I, Roa-Ureta RH, Bald C (2013) A new QSAR model, for angiotensin I-converting enzyme inhibitory oligopeptides. Food Chem 136(3):1370-1376

42. Wu J, Aluko RE, Nakai S (2006) Structural requirements of angiotensin I-converting enzyme inhibitory peptides: quantitative structure-activity relationship modeling of peptides containing 4-10 amino acid residues. OSAR Combinat Sci 25(10):873-880

43. Pripp AH, Isaksson T, Stepaniak L, Søhaug T (2004) Quantitative structure-activity relationship modelling of ACE-inhibitory peptides derived from milk proteins. Eur Food Res Technol 219(6):579-583

44. Kim SY, Je JY, Kim SK (2007) Purification and characterization of antioxidant peptide from hoki (Johnius belengerii) frame protein by gastrointestinal digestion. J Nutr Biochem 18(1):31-38

45. Ruiz-Giménez P, Marcos JF, Torregrosa G, Lahoz A, Fernández-Musoles R, Valles S, Alborch E, Manzanares P, Salom JB (2011) Novel antihypertensive hexa- and heptapeptides with ACE-inhibiting properties: from the in vitro ACE assay to the spontaneously hypertensive rat. Peptides 32(7):1431-1438

46. Kapel R, Rahhou E, Lecouturier D, Guillochon D, Dhulster P (2006) Characterization of an antihypertensive peptide from an Alfalfa white protein hydrolysate produced by a continuous enzymatic membrane reactor. Process Biochem 41(9):1961-1966

47. Pripp AH (2005) Initial proteolysis of milk proteins and its effect on formation of ACE-inhibitory peptides during gastrointestinal proteolysis: a bioinformatic, in silico, approach. Eur Food Res Technol 221(5):712-716

48. Wu J, Aluko RE (2007) Quantitative structure-activity relationship study of bitter di-and tri-peptides including relationship with angiotensin I-converting enzyme inhibitory activity. J Pept Sci 13(1):63-69

doi:10.1186/s40643-014-0017-5

Cite this article as: Liu et al:: Virtual screening for angiotensin Iconverting enzyme inhibitory peptides from Phascolosoma esculenta. Bioresources and Bioprocessing 2014 1:17.

\section{Submit your manuscript to a SpringerOpen ${ }^{\circ}$ journal and benefit from:}

- Convenient online submission

- Rigorous peer review

- Immediate publication on acceptance

- Open access: articles freely available online

- High visibility within the field

- Retaining the copyright to your article

Submit your next manuscript at $>$ springeropen.com 